\title{
Open Science at a time of the COVID-19 pandemic: a new opportunity to improve emergency response
}

\author{
Hanna Shmagun \\ Korea Institute of Science and \\ Technology Information (KISTI), \\ University of Science \\ and Technology (UST) \\ hanna.shmagun@gmail.com
}

\author{
Charles Oppenheim \\ Robert Gordon University \\ c.oppenheim@rgu.ac.uk
}

\author{
Jangsup Shim \\ Korea Advanced Institute of \\ Science and Technology (KAIST) \\ sjshl1iit@gmail.com
}

\author{
Kwang-Nam Choi \\ Korea Institute of Science and \\ Technology Information (KISTI) \\ knchoi@kisti.re.kr
}

\author{
Jaesoo Kim \\ Korea Institute of Science and \\ Technology Information (KISTI), \\ jaesoo@kisti.re.kr
}

\begin{abstract}
The ongoing COVID-19 pandemic has become a major milestone encouraging a change from traditional scholarly communication practices and policies in favour of greater openness, sharing, and reuse. Interviews with South Korean and Australian experts has helped to highlight the factors that either enable or limit the impact of Open Science during a public health emergency, such as the COVID-19 outbreak. The paper categorised such factors as: contextual and external; institutional and regulatory; resource-based; individual and motivational, and supplemented this categorisation with the interviewees' quotes to illustrate specific cases and examples. The institutional and regulatory factors are perceived as the most important ones by interviewees.
\end{abstract}

\section{Introduction}

The current coronavirus pandemic has revealed the vital importance of Open Science (OS) for effective emergency preparedness and response, according to international and national institutions [1]. Numerous OS initiatives and projects have emerged in the wake of the COVID-19 pandemics. These are challenging traditional science to become more open, global, collaborative, and closer to society.

For example, many large publishers have positively responded to the Open Access call [2] by providing free of charge access to some of their coronavirus-related publications for as long as the pandemic lasts. UNESCO has called on governments to reinforce scientific cooperation and integrate OS into their strategies to fight against the COVID-19 [1]. There have also been many initiatives related to opening up existing research data, such as virus genome sequences and protein structures, and offering access to data analysis tools $[3,4]$. Preprints have become a norm to report on the ongoing research results [5]. In comparison to previous major infectious diseases outbreaks, the scientific response to COVID-19 is unprecedented in terms of the speed of production and the scope of dissemination of scientific evidence [5-7].

However, despite the fact that the COVID-19 pandemic has highlighted the importance of OS, it has also highlighted the insufficient capacities of national scholarly communication systems to rapidly and effectively respond in times of emergency. Even the developed countries, which had already had prepandemic commitment to OS development, have shown the lack of comprehensive and consistent OS policies, inadequacy of cross-sectoral coordination mechanisms, and insufficiency of current incentive structures for researchers to pursue greater openness and collaboration [8]. Many initiatives launched during the current pandemic, such as open access to coronavirus-related publications, seem to be a temporary response to the crisis rather than the start of more sustainable structural changes in research culture [9]. International academic publishers are expected to return to their traditional subscription-based business model as soon as the pandemic is over, and much of the valuable scientific evidence related to infectious and other diseases, natural disasters and environmental problems will still be kept closed behind paywalls. 
The aim of this paper is to identify factors that are viewed by South Korean and Australian experts as enablers or barriers to OS practices in public health emergencies. We will address both pandemic-specific and broader relevant OS factors in the country-specific context.

\section{Literature review}

OS is a broad umbrella notion encompassing various practices aiming to remove barriers to knowledge creation and dissemination by maximising openness at each stage of the research life cycle thanks to the networking benefits of Information and Communication Technologies (ICT). This notion is applied to any field of knowledge, including science, social science and humanities. The best known OS practices are open access to scientific publications, open research data sharing, and open collaboration within and beyond research communities [10]. A distinctive feature of OS is reuse and sharing of scientific information viewed as OS data. These include the vigorously verified information at any phase of scientific enquiry that are findable, accessible, interoperable, reusable both by machines and by people (e.g., pre-registration plans, research data, papers, patents, research reports).

Previous studies have examined the factors influencing scientists' information sharing and/or reuse behaviour in general [11] or within particular disciplines for example, in health and life sciences [12], food science and technology [13], and astrophysics [14]. A widely cited study (co)-authored by Y. Kim argues that these factors can be categorised into four broad groups: (1) institutional factors, including funding agency's policy; (2) resource factors, including data repositories; (3) individual factors, including researchers' perceived efforts, benefits, and risks; and (4) other organisational and environmental factors [15].

However, only a few peer-reviewed studies, including position papers, have examined the emerging phenomenon of open scholarly communication in a public health emergency context [16-19]. There have also been a few studies and opinion pieces on the topic commissioned by international organisations. For example, in response to the previous SARS, MERS-CoV, Ebola and Zika outbreaks, the Wellcome Trust commissioned a study about policies, practices, and infrastructure supporting pathogens data sharing in public health emergencies [20]. Elsewhere, the Research Data Alliance (RDA) COVID-19 Working Group recently produced an initial set of guidelines for data sharing in the current pandemic with a focus on Omics ${ }^{1}$, Clinical Medicine, Epidemiology, and Social Sciences data [21]. The OECD's opinion piece "Why Open Science is critical to combatting COVID-19" presents some enablers and barriers of OS in the crisis [22]. One of the major deficiencies of such studies is a rather narrow focus on sharing research data within Biomedical Sciences and a lack of recommendations for the development of comprehensive national OS strategies.

We believe our research offers fresh insights for organisations dedicated to planning or improving national OS strategies in a more systematic and focused way. We highlight the importance of including the emergencyspecific mechanisms of effective communication of multiple information resources across different research domains into national OS strategies. In addition, our case study-based approach reveals certain cross-country differences in the field.

\section{Research approach and design}

We used a case study strategy, conducting semistructured interviews with South Korean (primarily) and Australian experts (Table 1). These countries have demonstrated a significant progress in adopting OS practices in the pre-pandemic period [23].

Using a purposive (expert/judgmental) sampling technique [24], a sample of fourteen people was formed to include researchers and practitioners from Biomedical and Health Sciences, S\&T policy, OS/Open Access areas, as well as those involved in scientific information service design and provision. The majority of interviewees (nine from fourteen) have research or job responsibilities related to COVID-19 or similar public health emergencies. Almost all (twelve of fourteen) interviewees have OS data reuse experience, and nine interviewees said to have OS data sharing experience.

Table 1. The profiles of interviewees

\begin{tabular}{|l|l|l|l|l|l|}
\hline $\mathbf{N}$ & Institution & Job title & PhD & Gender & $\begin{array}{l}\text { Experience in } \\
\text { the field at the } \\
\text { interview }\end{array}$ \\
\hline 1 & $\begin{array}{l}\text { Korean Bioinformation } \\
\text { Center (KOBIC) }\end{array}$ & $\begin{array}{l}\text { Senior } \\
\text { researcher }\end{array}$ & + & $\mathrm{M}$ & $1 \sim 5$ years \\
\hline 2 & $\begin{array}{l}\text { Korea Institute of } \\
\text { Science and } \\
\text { Technology } \\
\text { Information (KISTI) }\end{array}$ & $\begin{array}{l}\text { Principal } \\
\text { researcher }\end{array}$ & + & $\mathrm{M}$ & over 20 years \\
\hline 3 & $\begin{array}{l}\text { Korea Research } \\
\text { Institute of Chemical } \\
\text { Technology (KRICT) }\end{array}$ & $\begin{array}{l}\text { Principal } \\
\text { researcher }\end{array}$ & + & $\mathrm{M}$ & over 20 years \\
\hline 4 & $\begin{array}{l}\text { Korea Institute of } \\
\text { Science and } \\
\text { Technology (KIST) } / \\
\text { Biomedical Research } \\
\text { Institute }\end{array}$ & Researcher & $\begin{array}{l}\text { currently } \\
\text { enrolled }\end{array}$ & $\mathrm{F}$ & $1 \sim 5$ years \\
\hline 5 & $\begin{array}{l}\text { Korea Institute of } \\
\text { Science and } \\
\text { Technology } \\
\text { Information (KISTI) }\end{array}$ & $\begin{array}{l}\text { Principal } \\
\text { researcher }\end{array}$ & + & $\mathrm{M}$ & $6 \sim 10$ years \\
\hline 6 & $\begin{array}{l}\text { Chungnam National } \\
\text { University }\end{array}$ & Professor & + & $\mathrm{M}$ & $11 \sim 15$ years \\
\hline
\end{tabular}

${ }^{1}$ Omics data is high-throughput data from cell and molecular biology. 


\begin{tabular}{|l|l|l|l|l|l|}
\hline 7 & $\begin{array}{l}\text { Korea Institute of } \\
\text { Science and } \\
\text { Technology } \\
\text { Information (KISTI) }\end{array}$ & $\begin{array}{l}\text { Principal } \\
\text { researcher }\end{array}$ & + & M & $16 \sim 20$ years \\
\hline 8 & $\begin{array}{l}\text { Science and } \\
\text { Technology Policy } \\
\text { Institute (STEPI, Korea) }\end{array}$ & $\begin{array}{l}\text { Research } \\
\text { fellow }\end{array}$ & + & F & $6 \sim 10$ years \\
\hline 9 & $\begin{array}{l}\text { Korea Institute of } \\
\text { Science and } \\
\text { Technology (KIST) } \\
\text { Biomedical Research } \\
\text { Institute }\end{array}$ & Researcher & $\begin{array}{l}\text { currently } \\
\text { nnrolled }\end{array}$ & F & $1 \sim 5$ years \\
\hline 10 & $\begin{array}{l}\text { Korea Institute of } \\
\text { Science and } \\
\text { Technology } \\
\text { Information (KISTI), } \\
\text { Korea Research } \\
\text { Institute of Chemical } \\
\text { Technology (KRICT) }\end{array}$ & $\begin{array}{l}\text { Principal } \\
\text { researcher }\end{array}$ & + & M & $16 \sim 20$ years \\
\hline 11 & $\begin{array}{l}\text { Republic of Korea } \\
\text { Navy Marine Corps } \\
\text { (Medical service) }\end{array}$ & $\begin{array}{l}\text { Military } \\
\text { doctor }\end{array}$ & - & M & $1 \sim 5$ years \\
\hline 12 & $\begin{array}{l}\text { The Australian } \\
\text { Research Data } \\
\text { Commons (ARDC) }\end{array}$ & $\begin{array}{l}\text { Senior } \\
\text { research data } \\
\text { specialist }\end{array}$ & + & F & $11 \sim 15$ years \\
\hline 13 & $\begin{array}{l}\text { Cytrax Consulting } \\
\text { (Australia), RDA } \\
\text { consipul } \\
\text { (Cytrax } \\
\text { Consulting), } \\
\text { co-chair of } \\
\text { interest } \\
\text { groups } \\
\text { (RDA) }\end{array}$ & - & M & $1 \sim 5$ years \\
\hline 14 & $\begin{array}{l}\text { Access Strategy Group } \\
\text { (AOASG) }\end{array}$ & $\begin{array}{l}\text { Senior } \\
\text { manager }\end{array}$ & + & F & $16 \sim 20$ years \\
\hline
\end{tabular}

The questions for interviews were based on a systematic literature review followed by coding of the selected literature using NVivo 12 Plus software [25]. The PRISMA protocol [26] was used for identification, screening, and inclusion/exclusion of literature from Web of Science and SCOPUS databases. We used a combination of search terms including open science AND factors; open science AND enablers; open science AND barriers; scholarly communication AND epidemics; open science AND public health emergency; epidemics AND open research AND open access; open science AND data sharing AND COVID-19. We also searched for in-text cited references, studies published by international organisations (including OECD and the Wellcome Trust), relevant papers published by the target interviewees, COVID-19 Special Issue publications (e.g., The AsiaPacific Journal: Japan Focus, Special Issue "Pandemic Asia" [27]). We finally selected 93 papers for NVivo qualitative analysis.

NVivo analysis of the selected literature was based on a hybrid approach of deductive and inductive coding. Using a deductive coding approach, we created four categories known as 'nodes' pointing at the factors that affect OS practices, according to Kim's typology noted above (contextual or external factors, institutional and regulatory factors, resource factors, individual and motivational factors). Afterwards, the application of an open, axial, and selective coding of the selected literature has allowed for building a hierarchy of sub-factors ("child nodes'), which formed the basis for formulating the interview questions.

The interviews were conducted in May 2020 (Korean experts) and in September 2020 (Australian experts) using various methods (face-to-face interviews, telephone interviews, Zoom interviews, and email) as appropriate. All interviews were transcribed and analysed in NVivo following the same coding procedure as had been used for the literature review analysis. As a result, additional nodes were added to the taxonomy of factors, while some initially established nodes were revised.

\section{Results}

This study defined a set of factors affecting OS practices in public health emergencies, such as the COVID-19 crisis. Factors first identified from the literature review and then tested/supplemented by interviews, were placed into four groups. These were contextual or external factors (political and socioeconomic context, including public health emergency circumstances); institutional and regulatory factors (regulatory regime and leadership; interdisciplinary and cross-sector partnerships; and research communities' norms); resource factors (ICT infrastructure, financial and human resources); and individual and motivational factors (perceived personal efforts; perceived risk of negative consequences; perceived benefits; multiple dimensions of trust related to OS practices). The overview of all factors is summarised in Table 2.

Table 2. Taxonomy of factors affecting Open Science practices during the COVID-19 crisis

\begin{tabular}{|c|c|c|c|}
\hline 苍 & $\begin{array}{l}\text { Factors: } \\
\text { enablers, } \\
\text { \& barriers, } \\
\star \text { context-specific }\end{array}$ & Key point & Essential quotes \\
\hline 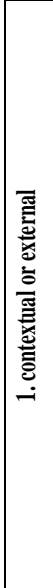 & $\begin{array}{l}\text { Emergency } \\
\text { experience }\end{array}$ & $\begin{array}{l}\text { Emergencies force to } \\
\text { develop the national } \\
\text { capacities for rapid } \\
\text { and effective cross- } \\
\text { sector collaboration } \\
\text { and coordination, } \\
\text { including open } \\
\text { communication } \\
\text { among scholars. }\end{array}$ & $\begin{array}{l}\text { "By the time we came } \\
\text { to COVID, we had } \\
\text { some lessons learned } \\
\text { from the bushfire } \\
\text { disasters, which } \\
\text { highlighted the need } \\
\text { for rapid } \\
\text { collaboration and } \\
\text { data sharing." (AU) } \\
\text { "Some countries are } \\
\text { beginning to realise } \\
\text { that pandemic has } \\
\text { made it absolutely } \\
\text { critical that they have a } \\
\text { national approach to } \\
\text { OS. That has happened } \\
\text { in Malaysia, for } \\
\text { example." (AU) }\end{array}$ \\
\hline
\end{tabular}




\begin{tabular}{|c|c|c|c|}
\hline & \begin{tabular}{|l} 
Factors: \\
$\bullet$ enablers, \\
barriers, \\
$\star$ context-specific
\end{tabular} & Key point & Essential quotes \\
\hline & Political openness & $\begin{array}{l}\text { In general, political } \\
\text { openness } \\
\text { democracy and } \\
\text { assumed to create } \\
\text { more space for OS. } \\
\text { However, it depends } \\
\text { on country } \\
\text { characteristics and } \\
\text { circumstances. In a } \\
\text { public realth } \\
\text { emergency, even } \\
\text { democratic countries } \\
\text { can employ some } \\
\text { authoritarian tools to } \\
\text { rapidly respond to } \\
\text { the emergency. }\end{array}$ & $\begin{array}{l}\text { "Authoritarian } \\
\text { countries can still } \\
\text { have OS.", "For } \\
\text { example, Singapore } \\
\text { is more like } \\
\text { authoritarian state, } \\
\text { but it has good OS } \\
\text { practices...Even } \\
\text { China adopted open } \\
\text { research r data } \\
\text { declaration last year." } \\
\text { (AU) }\end{array}$ \\
\hline & Globalisation & $\begin{array}{l}\text { Science diplomacy is } \\
\text { a factor that can push } \\
\text { many countries to } \\
\text { develop OS policy. }\end{array}$ & $\begin{array}{l}\text { "OS is a global idea, } \\
\text { trend and we are } \\
\text { trying to follow it as } \\
\text { other countries do." } \\
(\mathrm{KR})\end{array}$ \\
\hline & $\begin{array}{l}\text { Government- } \\
\text { citizen collaboration }\end{array}$ & $\begin{array}{lr}\text { Citizens' trust in and } \\
\text { support } & \text { for } \\
\text { government policy } \\
\text { positively affect } \\
\text { rapid r scholarly } \\
\text { communication and } \\
\text { cross-sector r } \\
\text { collaboration in an } \\
\text { emergency. }\end{array}$ & $\begin{array}{l}\text { "Korean people are } \\
\text { very collaborative } \\
\text { with government, } \\
\text { especially in any } \\
\text { crisis." (KR) } \\
\\
\end{array}$ \\
\hline & $\begin{array}{l}\diamond \text { Socio-political } \\
\text { conflicts }\end{array}$ & $\begin{array}{l}\text { Any international or } \\
\text { internal socio- } \\
\text { political conflict is a } \\
\text { limiting factor for } \\
\text { effective scholarly } \\
\text { communication } \\
\text { during an } \\
\text { emergency. }\end{array}$ & $\begin{array}{l}\text { "The conflict } \\
\text { between the US and } \\
\text { China over COVID- } \\
19 \text { slows down the } \\
\text { global cooperation } \\
\text { process, which can } \\
\text { also challenge OS } \\
\text { practices." (KR) }\end{array}$ \\
\hline & $\diamond$ Digital divide & $\begin{array}{l}\text { A problem of digital } \\
\text { divide should be } \\
\text { considered while } \\
\text { developing } \\
\text { policies in both } \\
\text { developed and } \\
\text { developing countries. }\end{array}$ & $\begin{array}{l}\text { "Research should be } \\
\text { carried out and } \\
\text { disseminated in both } \\
\text { ways (offline and } \\
\text { online). We cannot } \\
\text { totally replace } \\
\text { traditional science by } \\
\text { OS. It is only a } \\
\text { supplement to a } \\
\text { traditional scholarly } \\
\text { communication, } \\
\text { otherwise the } \\
\text { minority groups, such } \\
\text { as senior researchers } \\
\text { or the disabled, can } \\
\text { be discriminated." } \\
\text { (KR) }\end{array}$ \\
\hline
\end{tabular}

\begin{tabular}{|c|c|c|c|}
\hline 惫 & $\begin{array}{l}\text { Factors: } \\
\bullet \text { enablers, } \\
\star \text { barriers, } \\
\star \text { context-specific }\end{array}$ & Key point & Essential quotes \\
\hline & $\begin{array}{l}\star \text { Level of economic } \\
\text { development }\end{array}$ & $\begin{array}{l}\text { Developing countries } \\
\text { with low-resource } \\
\text { settings have an } \\
\text { investment demand for } \\
\text { more basic necessities to } \\
\text { improve people's } \\
\text { standard of living and } \\
\text { cannot afford additional } \\
\text { investment in scientific } \\
\text { infrastructure and } \\
\text { services. }\end{array}$ & $\begin{array}{l}\text { "In developing } \\
\text { countries, there is } \\
\text { usually a low status } \\
\text { of science and there is } \\
\text { a general opinion that } \\
\text { scientists live off the } \\
\text { state's generosity by } \\
\text { not producing } \\
\text { qualitative } \\
\text { outcomes." (KR) }\end{array}$ \\
\hline \multirow[b]{2}{*}{ 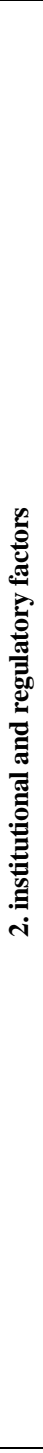 } & $\begin{array}{l}\text { National OS } \\
\text { policy leadership and } \\
\text { coordination }\end{array}$ & $\begin{array}{lr}\text { It should be a } \\
\text { national } & \text { OS } \\
\text { plan/strategy } & \text { through } \\
\text { which } & \text { diverse } \\
\text { interests and policies } \\
\text { are r reviewed, } \\
\text { adjusted r and } \\
\text { improved in } \\
\text { coordinated way. }\end{array}$ & $\begin{array}{l}\text { "One of our biggest } \\
\text { problem in Australia } \\
\text { is that we don't have } \\
\text { a national approach/ } \\
\text { strategy for OS." } \\
\text { (AU) } \\
\text { "Korea has a strong } \\
\text { Open Government } \\
\text { Data policy... but we } \\
\text { don't have a well- } \\
\text { developed, coherent } \\
\text { OS policy, such as in } \\
\text { the European Union." } \\
\text { (KR) }\end{array}$ \\
\hline & $\begin{array}{l}\star \text { Flexibility/rigor of } \\
\text { regulations in regard } \\
\text { to opening up } \\
\text { scientific evidence } \\
\\
\end{array}$ & $\begin{array}{lr}\text { Legally } & \text { binding } \\
\text { instruments } & \text { and } \\
\text { enforcement } \\
\text { mechanisms } \\
\text { DMP) imposed by } \\
\text { government research } \\
\text { funders can promote } \\
\text { OS } & \text { practices, } \\
\text { especially in } & \text { an } \\
\text { emergency. However, } \\
\text { overregulation can be } \\
\text { a burden rand } \\
\text { demotivation rar for } \\
\text { scientists to carry out } \\
\text { government-funded } \\
\text { research. }\end{array}$ & $\begin{array}{l}\text { "Research data } \\
\text { sharing is encouraged } \\
\text { but not explicitly } \\
\text { mandated yet." (AU) } \\
\text { "Making research } \\
\text { data open, reusable, } \\
\text { findable requires a } \\
\text { lots of efforts. } \\
\text { Researchers are } \\
\text { already busy. If you } \\
\text { make data sharing } \\
\text { mandatory, should } \\
\text { researchers shift the } \\
\text { other 10-20\% of their } \\
\text { duties to research } \\
\text { data management or } \\
\text { do you have a new } \\
\text { workforce to help } \\
\text { researchers to do } \\
\text { that? I don't think it } \\
\text { should be strictly } \\
\text { mandatory." (AU) }\end{array}$ \\
\hline
\end{tabular}




\begin{tabular}{|c|c|c|c|}
\hline : & $\begin{array}{l}\text { Factors: } \\
\text { enablers, } \\
\star \text { barriers, } \\
\star \text { context-specific }\end{array}$ & Key point & Essential quotes \\
\hline & $\begin{array}{l}\text { Fast tracks for } \\
\text { procedures involved } \\
\text { in a research life } \\
\text { cycle (i.e. data } \\
\text { production, sharing } \\
\text { of preliminary } \\
\text { findings, data and } \\
\text { final results } \\
\text { publishing) }\end{array}$ & $\begin{array}{l}\text { The important } \\
\text { requirement for } \\
\text { scholarly } \\
\text { communication in an } \\
\text { emergency situation is } \\
\text { to share scientific } \\
\text { evidence as soon as } \\
\text { possible. }\end{array}$ & $\begin{array}{l}\text { "Local Korean } \\
\text { journals and research } \\
\text { communities have } \\
\text { not been ready } \\
\text { enough for expedited } \\
\text { peer-reviewed } \\
\text { publication, though } \\
\text { somer domestic } \\
\text { preprint services have } \\
\text { been newly } \\
\text { developed." (KR) }\end{array}$ \\
\hline & $\begin{array}{l}\text { Measures to } \\
\text { ensure quality } \\
\text { control, legal and } \\
\text { ethical compliance }\end{array}$ & $\begin{array}{l}\text { The establishment of } \\
\text { a National Research } \\
\text { Ethics Committee is } \\
\text { important. This body } \\
\text { can provide peer- } \\
\text { review of the critical } \\
\text { scientific evidence, } \\
\text { make a decision on } \\
\text { OS practices while } \\
\text { striking the right } \\
\text { balance between } \\
\text { collective interests } \\
\text { (public health) and } \\
\text { individual interests } \\
\text { (privacy, IPR), etc. }\end{array}$ & $\begin{array}{l}\text { "The urgency of } \\
\text { getting information } \\
\text { for the sake of public } \\
\text { health interest may } \\
\text { have greater priority } \\
\text { than privacy } \\
\text { concerns." (KR) } \\
\text { "You cannot just say } \\
\text { that there is no } \\
\text { privacy rights } \\
\text { because we are in a } \\
\text { pandemic" (AU) }\end{array}$ \\
\hline & $\begin{array}{l}\text { Systematic policy } \\
\text { of OS incentives for } \\
\text { researchers }\end{array}$ & $\begin{array}{l}\text { The incentives are } \\
\text { especially needed to } \\
\text { motivate scholars to } \\
\text { share their research } \\
\text { data, since the } \\
\text { process to prepare } \\
\text { research data for } \\
\text { reuse requires lots of } \\
\text { efforts and time. }\end{array}$ & $\begin{array}{l}\text { "I think it is a huge } \\
\text { problem. } \\
\text { systematic approach } \\
\text { to develop different } \\
\text { kinds of incentives, } \\
\text { general and } \\
\text { emergency-specific, } \\
\text { is needed." (KR) }\end{array}$ \\
\hline & $\begin{array}{l}\text { Interdisciplinary } \\
\text { and cross-sector } \\
\text { partnerships (e.g., } \\
\text { government, research } \\
\text { institutes, hospitals, } \\
\text { industry) }\end{array}$ & $\begin{array}{l}\text { It is important to } \\
\text { have a mediator } \\
\text { (organisation) to } \\
\text { foster emergency- } \\
\text { related partnerships. } \\
\text { It can be done } \\
\text { through funding } \\
\text { models, } \\
\text { coordination, } \\
\text { building skills, } \\
\text { providing facilities } \\
\text { and data linkage, } \\
\text { dissemination of } \\
\text { projects outcomes. }\end{array}$ & 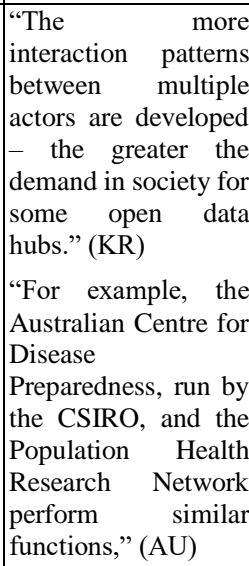 \\
\hline
\end{tabular}

\begin{tabular}{|c|c|c|c|}
\hline 苍 & $\begin{array}{l}\text { Factors: } \\
\text { e enablers, } \\
\text { barriers, } \\
\star \text { context-specific }\end{array}$ & Key point & Essential quotes \\
\hline & $\begin{array}{l}\star \text { Research } \\
\text { communities' norms }\end{array}$ & $\begin{array}{l}\text { Some disciplines } \\
\text { have a stronger OS } \\
\text { culture: for example, } \\
\text { Astronomy, Earth } \\
\text { Science, High-Energy } \\
\text { Physics, Biomedical } \\
\text { Science (Genomics). } \\
\text { The maturity of } \\
\text { discipline, long } \\
\text { history of } \\
\text { international } \\
\text { scientific } \\
\text { collaboration, } \\
\text { research with less } \\
\text { sensitive information } \\
\text { determine the OS } \\
\text { culture. }\end{array}$ & $\begin{array}{l}\text { "OS more comes } \\
\text { from research } \\
\text { communities of } \\
\text { practice, which push } \\
\text { government } \\
\text { policies." (AU) } \\
\text { "Sometimes there are } \\
\text { disciplines doing } \\
\text { better than others, } \\
\text { because they have to } \\
\text { collaborate by sharing } \\
\text { results globally." } \\
\text { (AU) }\end{array}$ \\
\hline & $\begin{array}{l}\text { Interoperability } \\
\text { of ICT infrastructure }\end{array}$ & $\begin{array}{l}\text { Interoperable data } \\
\text { exchange between } \\
\text { heterogeneous } \\
\text { scientific and cross- } \\
\text { sector systems is very } \\
\text { important. }\end{array}$ & $\begin{array}{l}\text { "Interoperability is } \\
\text { really a big issue. We } \\
\text { are not doing terribly } \\
\text { well yet. What we } \\
\text { need are data } \\
\text { exchange standards } \\
\text { implemented by data } \\
\text { infrastructure } \\
\text { providers } \\
\text { beforehand." (AU) }\end{array}$ \\
\hline 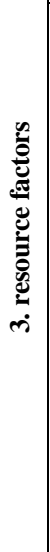 & $\begin{array}{l}\text { Operational } \\
\text { Readiness Levels } \\
(\text { ORL) of data }\end{array}$ & $\begin{array}{l}\text { A classification } \\
\text { framework of the } \\
\text { quality/trustworthine } \\
\text { ss of all content on } \\
\text { OS platforms for } \\
\text { rapid data-driven } \\
\text { decision making } \\
\text { should be } \\
\text { established. The } \\
\text { ORL framework, } \\
\text { developed by the } \\
\text { Disaster Lifecycle } \\
\text { Cluster at the Earth } \\
\text { Science Information } \\
\text { Partners community, } \\
\text { can serve as a } \\
\text { reference model. }\end{array}$ & $\begin{array}{l}\text { "Operational } \\
\text { readiness of data is } \\
\text { something that's } \\
\text { absolutely critical } \\
\text { and that is missing in } \\
\text { lots of infrastructures } \\
\text { globally. We have } \\
\text { lots of data, but we } \\
\text { don't have the } \\
\text { mechanisms to make } \\
\text { it operationally } \\
\text { useful in a real-life } \\
\text { scenario." (AU) }\end{array}$ \\
\hline
\end{tabular}




\begin{tabular}{|c|c|c|c|}
\hline 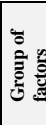 & $\begin{array}{l}\text { Factors: } \\
\bullet \text { enablers, } \\
\text { b barriers, } \\
\star \text { context-specific }\end{array}$ & Key point & Essential quotes \\
\hline & $\begin{array}{l}\text { Automatic } \\
\text { regulatory } \\
\text { compliance } \\
\text { embedded in } \\
\text { scientific information } \\
\text { services }\end{array}$ & $\begin{array}{l}\text { For example, it can be } \\
\text { applied to check if the } \\
\text { research grant applicant } \\
\text { submitted DMP in a } \\
\text { proper form, if the user } \\
\text { of CC-BY licensed } \\
\text { content properly } \\
\text { attributed the author, if } \\
\text { research data/outcome } \\
\text { being uploaded to a } \\
\text { system do not contain } \\
\text { any privacy-sensitive } \\
\text { information. } \\
\text { Blockchain and } \\
\text { intelligent software } \\
\text { agents can support this. }\end{array}$ & $\begin{array}{l}\text { "To make this } \\
\text { possible, } \\
\text { interoperability and } \\
\text { linkage of data are } \\
\text { important...I think } \\
\text { lots of things we are } \\
\text { doing today can be } \\
\text { automated. But at the } \\
\text { current stage, when } \\
\text { machines cannot } \\
\text { teach themselves to } \\
\text { learn, you need hard- } \\
\text { coded rules and } \\
\text { standards for } \\
\text { compliance } \\
\text { procedures." (AU) }\end{array}$ \\
\hline & $\begin{array}{l}\text { Financial } \\
\text { resources }\end{array}$ & $\begin{array}{l}\text { The government } \\
\text { should provide rapid } \\
\text { funding for } \\
\text { prioritised areas of } \\
\text { research and relevant } \\
\text { OS infrastructure. }\end{array}$ & $\begin{array}{l}\text { "The government } \\
\text { pretty quickly put } \\
\text { some extra money to } \\
\text { fund pandemic- } \\
\text { related research. To } \\
\text { fund OS } \\
\text { infrastructure - there } \\
\text { is no something I } \\
\text { have seen to put } \\
\text { forward in the } \\
\text { pandemic." (AU) } \\
\text { "In this pandemic we } \\
\text { had to use our own, } \\
\text { very limited budget } \\
\text { to rapidly launch a } \\
\text { data service related to } \\
\text { the outbreak ... There } \\
\text { is a complicated } \\
\text { procedure, money } \\
\text { cannot easily flows } \\
\text { from the government } \\
\text { to public research } \\
\text { institutes." (KR) }\end{array}$ \\
\hline & $\begin{array}{l}\text { Open Science } \\
\text { education }\end{array}$ & $\begin{array}{l}\text { Research institutes, } \\
\text { datar rervice } \\
\text { providers and other } \\
\text { agencies rhould } \\
\text { assist researchers in } \\
\text { data sharing, data } \\
\text { management, and } \\
\text { data reuse practices. }\end{array}$ & $\begin{array}{l}\text { "Korean researchers } \\
\text { have the ICT skills to } \\
\text { use generic } \\
\text { information systems } \\
\text { and web services, but } \\
\text { the problem is that } \\
\text { researchers do not } \\
\text { know much about OS } \\
\text { services: where to } \\
\text { upload my data, where } \\
\text { to access other } \\
\text { researchers' data and } \\
\text { why I should do it..." } \\
\text { (KR) } \\
\text { "We should educate } \\
\text { people how to search } \\
\text { for scientific content } \\
\text { and how to judge its } \\
\text { quality." (AU) }\end{array}$ \\
\hline
\end{tabular}

\begin{tabular}{|c|c|c|c|}
\hline 总 & $\begin{array}{l}\text { Factors: } \\
\bullet \text { enablers, } \\
\text { barriers, } \\
\star \text { context-specific }\end{array}$ & Key point & Essential quotes \\
\hline & $\begin{array}{l}\text { Expert groups for } \\
\text { rapid peer-review of } \\
\text { research } \\
\text { data/outcomes }\end{array}$ & $\begin{array}{l}\text { The } r \text { emergency- } \\
\text { related information } \\
\text { sharing should be } \\
\text { preceded by a solid } \\
\text { fact-checking and } \\
\text { scientific peer-review } \\
\text { process, r but } \\
\text { performed at high } \\
\text { speed. There is a need } \\
\text { to employ additional } \\
\text { experts during an } \\
\text { emergency. }\end{array}$ & $\begin{array}{l}\text { "The real challenge is } \\
\text { not enough people to } \\
\text { do rapid peer- } \\
\text { review... Proper } \\
\text { structured reporting of } \\
\text { research evidence } \\
\text { (paper, data) is also } \\
\text { important for this." } \\
\text { (AU) }\end{array}$ \\
\hline & $\begin{array}{l}\text { Professionals } \\
\text { creating and } \\
\text { delivering the } \\
\text { evidence-based } \\
\text { popular science } \\
\text { content }\end{array}$ & $\begin{array}{l}\text { The } r \text { government } \\
\text { should } r \text { provide } \\
\text { commercial } \\
\text { opportunities } \\
\text { alternative } \\
\text { organisations } \\
\text { professionals, and } \\
\text { as such } \\
\text { journalists, who are } \\
\text { much more capable } \\
\text { to create popular } \\
\text { science content and } \\
\text { communicate it to the } \\
\text { public. } \\
\end{array}$ & $\begin{array}{l}\text { "In order that } \\
\text { ordinary people pay } \\
\text { attention to scientific } \\
\text { information, } \\
\text { understand it, and } \\
\text { benefit from its use in } \\
\text { daily life, such } \\
\text { information should } \\
\text { be really interesting } \\
\text { and easy to } \\
\text { understand. It can be, } \\
\text { for example, } \\
\text { infographics, } \\
\text { summary of research } \\
\text { findings in a story- } \\
\text { writing style, Q\&A } \\
\text { interviews } \\
\text { researchers." (KR) }\end{array}$ \\
\hline 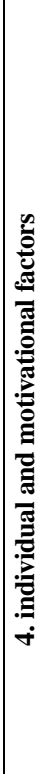 & $\begin{array}{l}\diamond \text { Perceived } \\
\text { personal efforts, } \\
\text { concerns, risk of } \\
\text { negative } \\
\text { consequences }\end{array}$ & \begin{tabular}{|l|} 
Researchers' perceived \\
concerns: concern \\
about compliance with \\
personal data \\
protection law; concern \\
of being "scooped"; \\
fear to lose reputation \\
because of the revealed \\
mistakes, etc.
\end{tabular} & $\begin{array}{l}\text { "Researchers want to } \\
\text { exploit maximum use } \\
\text { of dataset they have } \\
\text { generated. It prevails } \\
\text { in the Humanity } \\
\text { sector. There is an } \\
\text { academic } \\
\text { competition. If you } \\
\text { make your dataset } \\
\text { publicly available, } \\
\text { you give away your } \\
\text { competitive } \\
\text { advantage. Because } \\
\text { you can ask different } \\
\text { research questions } \\
\text { using the same } \\
\text { dataset and publish } \\
\text { different papers. } \\
\text { Some researchers } \\
\text { who collected good } \\
\text { data during their } \\
\text { early career can use it } \\
\text { for the entire } \\
\text { academic life." (AU) }\end{array}$ \\
\hline
\end{tabular}




\begin{tabular}{|c|c|c|c|}
\hline $\begin{array}{l}\overline{\mathrm{o}} \\
\overline{\bar{t}} \\
\overline{\mathrm{t}}\end{array}$ & \begin{tabular}{|l|} 
Factors: \\
$\bullet$ enablers, \\
barriers, \\
$\star$ context-specific
\end{tabular} & Key point & Essential quotes \\
\hline & Perceived benefits & 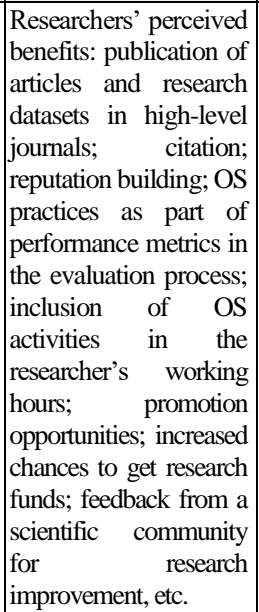 & $\begin{array}{l}\text { "I am not altruist by } \\
\text { nature. For me, } \\
\text { motivation to share } \\
\text { my data would be } \\
\text { promotion, building } \\
\text { reputation in my } \\
\text { field..." (KR) }\end{array}$ \\
\hline & Trust in OS & $\begin{array}{l}\text { Dimensions of OS } \\
\text { trust: trust in science } \\
\text { and scientists; trust in } \\
\text { data service provider } \\
\text { (institution); trust in } \\
\text { data platform } \\
\text { (service); trust in } \\
\text { data quality; trust in } \\
\text { research community } \\
\text { with Open Science } \\
\text { experience; trust in } \\
\text { reciprocal action. }\end{array}$ & $\begin{array}{l}\text { "Researcher's } \\
\text { reliance on OS } \\
\text { experiences within a } \\
\text { research community } \\
\text { is the most important } \\
\text { issue. If you share, } \\
\text { the others will share } \\
\text { with you." (AU) }\end{array}$ \\
\hline
\end{tabular}

As part of the interviews, we asked the respondents to rank the four identified groups of factors using a 1-4 scale (" 1 " is the most important and " 4 " is the least important group of factors). The results are presented in Table 3.

Table 3. Ranking data of factors affecting Opens Science practices

\begin{tabular}{|c|c|c|c|c|}
\hline $\begin{array}{l}\text { Intervie } \\
\text { wees }\end{array}$ & $\begin{array}{l}\text { Contextual/ } \\
\text { external } \\
\text { factors }\end{array}$ & $\begin{array}{l}\text { Institutional/ } \\
\text { regulatory } \\
\text { factors }\end{array}$ & $\begin{array}{l}\text { Resource } \\
\text { factors }\end{array}$ & $\begin{array}{l}\text { Individual/ } \\
\text { motivational } \\
\text { factors }\end{array}$ \\
\hline N 1 & 1 & 2 & 4 & 3 \\
\hline N 2 & 3 & 3 & 2 & 4 \\
\hline N 3 & 1 & 1 & 1 & 4 \\
\hline N 4 & 1 & 1 & 3 & 2 \\
\hline N 5 & 4 & 4 & 2 & 3 \\
\hline N 6 & 1 & 1 & 3 & 2 \\
\hline N 7 & 4 & 3 & 4 & 1 \\
\hline N 8 & 2 & 1 & 3 & 2 \\
\hline N 9 & 4 & 1 & 3 & 4 \\
\hline N 10 & 2 & 1 & 3 & 4 \\
\hline N 11 & 2 & 1 & 4 & 2 \\
\hline N 12 & 3 & 2 & 3 & 1 \\
\hline N 13 & 4 & 3 & 4 & 1 \\
\hline N 14 & 2 & 25 & 41 & 34 \\
\hline Value & 34 & $\mathbf{1 . 8}$ (I) & $\mathbf{2 . 9}$ (III) & $\mathbf{2 . 4}$ (II) \\
\hline Averagerank & $\mathbf{2 . 4}$ (II) & & & \\
\hline & & & 2 & 1 \\
\hline
\end{tabular}

The institutional and regulatory factors were named as the most important group. Two other groups comprising individual and motivational factors and contextual or external factors were ranked second. Finally, resource factors were perceived by interviewees as the least important group of factors. "I believe if you have a relevant policy and individual willingness, you can find resources for OS. But if policy-makers and researchers are against it, resources will not be allocated and used," said an interviewee. It should be noted that one of the interviewees assigned the same degree of importance to all the identified factor groups not being able to discriminate between them and arguing that OS is dependent on different combinations of all factors. Some respondents argued that the COVID-19 pandemic significantly increases the impact of contextual/external factors on OS development.

\section{Discussion and conclusions}

In this study, we have identified diverse factors influencing attitudes to OS data sharing and reuse practices in public health emergencies, such as the current COVID-19 pandemic. We have divided these factors into four broad groups (contextual or external, institutional and regulatory, resource, individual and motivational factors), classified them as enablers, barriers, or context-specific factors, and presented the key results in a table format. Each factor is accompanied with real-life examples provided by relevant interviewee responses. In addition, we gave a score to each of the four groups of factors based on its priority to the experts who we interviewed.

The institutional and regulatory factors, such as laws, pressures by funding agencies and journal publishers, legally-binding partnerships, research communities' norms, are perceived as primary factors which can significantly foster or hamper OS practices. Although OS practices are technically feasible with the advanced ICT, multiple legal and ethical impediments, particularly related to research data sharing, still continue to exist [28]. For example, among the gaps are ambiguity about protection of research data as intellectual property, a lack of policies to make OS practices a part of performance metrics in the research evaluation process. The OS practices in a public health emergency situation require also additional policies to put in place - such as expedited procedures for development, evaluation, and dissemination of scientific evidence, with embedded quality control and protection of researchers and human research subjects' interests.

According to the responses of experts from South Korea and Australia, both countries have not still developed a comprehensive national strategy and 
regulatory regime for OS. This was perceived by the interviewees to be a significant obstacle to effective scholarly communication in both emergency and nonemergency situations. However, the pre-pandemic continuous commitment of both countries towards OS development, as a component of emergency preparedness, has positively affected their responses to COVID-19. South Korea has learned some lessons from the Severe Acute Respiratory Syndrome (SARS-CoV) and the Middle East Respiratory Syndrome (MERS$\mathrm{CoV}$ ) outbreaks, while Australia has realised the importance of scientific information sharing and crosssector collaboration being familiar with the devastation of natural hazards, such as bushfires. Thus, by the time the COVID-19 pandemic hit, both these ICT-advanced countries had already had some basic infrastructure for OS. In particular, the Korea Institute of Science and Technology Information/KISTI (in Korea) and the Australian Research Data Commons/ARDC (in Australia) have had a key role in constructing such infrastructure and providing relevant data services. Nevertheless, a national ICT infrastructure for OS was perceived by interviewees from both countries as not properly developed yet. In particular, the issue of interoperability was pointed out.

Based on our results, we found that South Korea adheres to a rather top-down approach to OS, while the Australian approach to OS is largely dependent on bottom-up forces. In Korea, the government sector, including the Ministry of Science and ICT and the subordinate KISTI, has a leadership role in promoting OS policies and maintaining ICT infrastructure for OS data services. In Australia, different research communities and interest groups drive the adoption of OS policies and practices [29]. Their activities are coordinated by ARDC (limited company), which is the main OS data service provider in Australia.

The overall findings of this study show that multiple processes, including normative structures and basic infrastructure, should be systematically prepared before a crisis hits. A national scholarly communication system based on OS principles cannot be built overnight in sudden crisis situations, even though some tools, such as crowdsourced data collections, can be hastily provided.

We are aware of the limitations of the study: the small sample of interviews, biased towards researchers from South Korea, and the qualitative nature of research limit generalisation of the findings; the approach to rank the groups of factors is inevitably simplistic. Nevertheless, we hope that our study contributes to the OS theory and does provide insights for policy-makers about what are perceived are the key factors of OS practices in public health emergencies.
As part of the next phase of the research, we are interviewing experts from other countries and from more diverse fields, including government research funders, R\&D managers, data service providers, and publishers. The results from all these interviews will be used as inputs for a structured questionnaire, which will targeted at multiple stakeholders in South Korea. We also will develop a conceptual model of an ideal national OS Ecosystem with the capacity to respond in public health emergencies. The design of the conceptual model will draw on Ostrom's Institutional Analysis and Development (IAD) analytical framework [30]. The conceptual model will be built as a practicable analytical tool for science and technology managers and researchers alike to incorporate OS-based multidisciplinary communication into all stages of research planning and implementation. It will also be able to serve as a conceptual instrument to assess and recommend improvements to national OS policies and practices. A preliminary model of such an OS Ecosystem is presented in Figure 1 and is a result of some of our previous research [31].

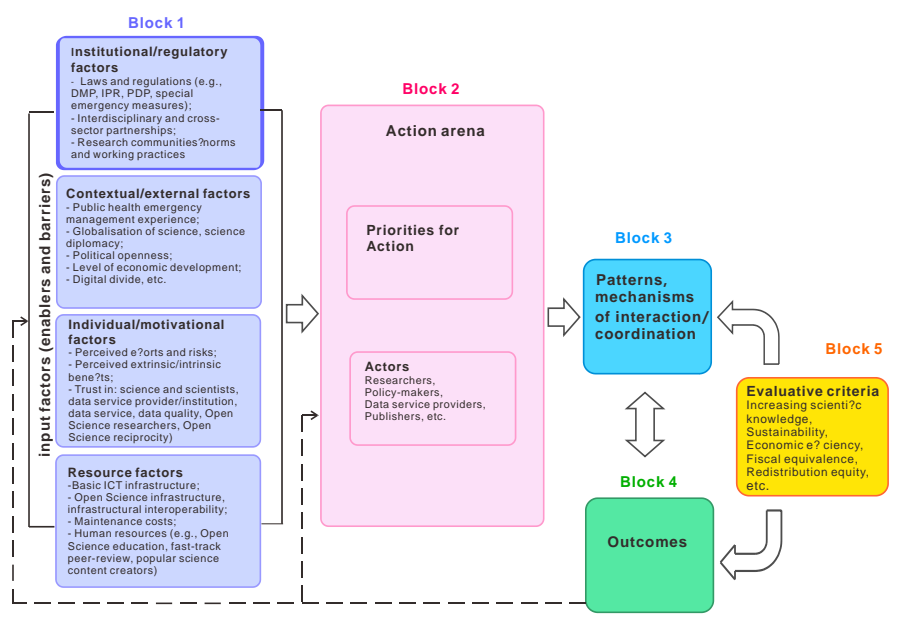

Figure 1. A preliminary conceptual model of Open Science Ecosystem (adapted from Ostrom's IAD Framework)

\section{Acknowledgement}

This research was supported by the Korea Institute of Science and Technology Information (KISTI) (NTIS No. 1711120559). 


\section{References}

[1] UNESCO, "UNESCO mobilizes 122 countries to promote open science and reinforced cooperation in the face of COVID-19”, 2020. [Online]. Available: en.unesco.org/news/unesco-mobilizes-122-countries-pro mote-open-science-and-reinforced-cooperation-facecovid-19. [Accessed 01-July-2020].

[2] Government of Canada, "Call for Open Access to COVID19 Publications", 2020. [Online]. Available: https://www.ic.gc.ca/eic/site/063.nsf/eng/h_98016.html. [Accessed 01-July-2020].

[3] COVID-19 Data Portal. [Online] Available: https://www.covid19dataportal.org/. [Accessed 01July-2020].

[4] COVID-19 Research Information Portal (Korea). [Online]. Available: https://www.kobic.re.kr/covid19/. [Accessed 01July-2020].

[5] N. Fraser et al., "Preprinting a pandemic: the role of preprints in the COVID-19 pandemic", bioRxiv, 2020. [Online]. Available: https://www.biorxiv.org/content/10.1101/2020.05.22.111294v 1. [Accessed 01-July-2020].

[6] J.A. Helliwell et al., "Global academic response to COVID19: Cross-sectional study”, Learned Publishing, 33(4) Early View, 2020. [Online]. Available: https://onlinelibrary.wiley.com/doi/10.1002/leap.1317. [Accessed 01-August-2020].

[7] COMMS (punctum books), "Viral Open Access in Times of a Global Pandemic", 2020. [Online]. Available: https://punctumbooks.pubpub.org/pub/viral-open-accessglobal-pandemic-covid-19-corona/release/3. [Accessed 01August-2020].

[8] Asia Open Access Meeting 2020, conference materials. [Online]. Available: https://2020korea.asiaoa.org/. [Accessed 20-September-2020].

[9] Australian Academy of Science, V. Barbour, M. Borchert, "Open science: after the COVID-19 pandemic there can be no return to closed working", 2020. [Online]. Available: https://www.science.org.au/curious/policy-features/openscience-after-covid-19-pandemic-there-can-be-no-returnclosed-working.[Accessed20-September-2020].

[10] OECD, "Making Open Science a Reality", OECD Science, Technology and Industry Policy Papers, No. 25, OECD Publishing, Paris, 2015.

[11] C. Tenopir et al., "Data sharing, management, use, and reuse: Practices and perceptions of scientists worldwide", PloS One, 15(3), 2020.

[12] J. Park and J. L. Gabbard, "Factors that affect scientists' knowledge sharing behavior in health and life sciences research communities: differences between explicit and implicit knowledge", Computers in Human Behavior, 78, 2018, pp. 326-335.

[13] R. Melero and C. Navarro-Molina, "Researchers' attitudes and perceptions towards data sharing and data reuse in the field of food science and technology", Learned Publishing, 33(2), 2020, pp. 163-179.

[14] A. Zuiderwijk and H. Spiers, "Sharing and re-using open data: A case study of motivations in astrophysics", International Journal of Information Management, 49, 2019, pp. 228-241.
[15] Y. Kim and J.M. Stanton, "Institutional and individual factors affecting scientists' data-sharing behaviors: A multilevel analysis", Journal of the Association for Information Science and Technology, 67(4), 2016, pp. 776-799.

[16] M.P. da Costa and F.C.L. Leite, "Factors influencing research data communication on Zika virus: a grounded theory", Journal of Documentation, 75, 2019, pp. 910-926.

[17] K. Modjarrad et al., "Developing global norms for sharing data and results during public health emergencies", PLoS Medicine, 13(1), 2016.

[18] C.D.S. Ribeiro et al., "How ownership rights over microorganisms affect infectious disease control and innovation: a root-cause analysis of barriers to data sharing as experienced by key stakeholders", PloS One, 13(5), 2018.

[19] J.P. Chretien, C.M. Rivers, and M.A. Johansson, "Make data sharing routine to prepare for public health emergencies", PLoS Medicine, 13(8), 2016.

[20] Wellcome Trust, "Data sharing in public health emergencies. A study of current policies, practices and infrastructure supporting the sharing of data to prevent and respond to epidemic and pandemic threats", 2018. [Online]. Available: https://wellcome.figshare.com/ndownloader/files/1050607. [Accessed 01-July-2020].

[21] RDA COVID-19 Working Group, "Recommendations and Guidelines on data sharing", 2020. [Online]. Available: https://zenodo.org/record/3932953\#.X3mm82gzZPY. [Accessed 01-July-2020].

[22] OECD, "Why open science is critical to combatting COVID19”, 2020. [Online]. Available: http://www.oecd.org/coronavirus/policy-responses/whyopen-science-is-critical-to-combatting-covid-19-cd6ab2f9/. [Accessed 01-July-2020].

[23] Science|Business, "Going global: connecting the clouds", $2020 . \quad$ [Online]. Available: https://sciencebusiness.net/report/going-global-connectingclouds. [Accessed 01-July-2020].

[24] A.J. Pickard, Research Methods in Information (2nd ed.), Facet Publishing, London, 2013.

[25] K. Jackson and P. Bazeley, Qualitative Data Analysis with NVivo (3rd ed.), SAGE Publications, London, 2019.

[26] D. Moher et al., "Preferred Reporting Items for Systematic Reviews and Meta-Analyses: The PRISMA Statement", PLoS Medicine, 6(7), 2009.

[27] The Asia-Pacific Journal: Japan Focus, "Special Issue: Pandemic Asia, Part I", 2020. [Online]. Available: https://apjjf.org/2020/14/APJ.html. [Accessed 01-August2020].

[28] H.N.M. Hashim, "Developing a Model Guidelines Addressing Legal Impediments to Open Access to Publicly Funded Research Data in Malaysia", Data Science Journal, 18, art. 27, 2019.

[29] Australian Research Data Commons, Communities of practice. [Online]. Available: https://ardc.edu.au/resources/communities-of-practice/. [Accessed20-September-2020].

[30] E. Ostrom and C. Hess, "A Framework for Analyzing the Knowledge Commons", Understanding Knowledge as a Commons: From Theory to Practice, MIT Press, Cambridge 2011,pp. 41-81.

[31] H. Shmagun, J. Shim, Y. Shin, M. Yang, and J. Kim, "COVID-19 와 같은 공공보건 비상사태에서 
오픈사이언스 생태계의 개념적 프레임워크 개발 방법 연구: 진행 중인 연구의 단계적 결과 중심

(Conceptual Framework of Open Science Ecosystem for Public Health Emergencies such as COVID-19: preliminary results from ongoing research)", in Proceedings of the KOTIS 2020 Fall Conference, November 2020, pp. 178-187. 